\title{
THE CONTENT OF COURSES IN LEGISLATION
}

\author{
BY WILLARD HURST*
}

$\mathrm{I}^{\mathrm{Be}}$ ISLATION still has to win its place in most law schools as a separate focus of the curriculum. Those who see in this situation a fundamental weakness of the typical law training will welcome the publication of Professor Horack's casebook, ${ }^{x}$ both as a stimulus to schools not yet experimenting, and as a suggestive base of comparison to those already testing their own ideas. Four years of trial and error in this field at Wisconsin do not entitle me to the dogmatism of writing a standard review of a casebook whose editor, after ten years of background work, finds his "undertaking hazardous and the result experimental." But they do permit exchange and criticism of experience in an area where aims and methods are still wide open for discussion.

The importance of legislation in the body of the law today, from a statute of Congress to a regulation of an industrial commission or an ordinance of a city council, is a commonplace. Further, there has been a growing separation and specialization of the agencies which determine policy and formulate standards and rules. And as policy is expressed in more and more inclusive and complicated regulations, its practical significance depends increasingly upon the skill and sympathy of those who are engaged in its interpretation and application. The specialization of the policy-making function and the heightened importance of policy application mean that lawmen have greater need for a working philosophy and trained intuition in the adjustment of the relationships of legal agencies.

\section{LEGISLATIVE ORGANIZATION AND PROCEDURE}

The conventional curriculum can offer the student little opportunity to become acquainted with essential problems in the functioning of the legislative process itself. A good deal of the law relating to the machinery of legislation-introduction of bills, consideration before committee and the full house, executive action-is straightforward, matter-of-fact doctrine on which background reading should suffice, without encroachment upon classroom hours. Professor Horack's chapter on "Legislative Organiza-

* Assistant Professor of Law, University of Wisconsin.

× Cases and Materials on Legislation. By Frank E. Horack, Jr. Chicago: Callaghan \& Co., I940. Pp. xxix, 829. \$7.00. 
tion and Procedure" follows the common-sense line of recent casebook construction, in using extensive editorial notes to present such material. His text, moreover, overruling departmental boundaries, seeks to place the legal issues in the living context of the political problems involved in legislative mechanics. Particularly important is the emphasis on the committee system. Indeed, the lawyer's job as advocate in the legislative process so centers on the committee stage, in the presentation of evidence and argument or in the representation of a client called to act as a witness, as to deserve more attention than the editor allows it. ${ }^{2}$

Three legal issues of legislative procedure, two involving the committee stage, possess the root importance, the movement and the color which call for discussion. In the first place, Professor Horack does not, curiously, explore the extent to which due process may require notice and hearing for the enactment of legislative regulations. The question provokes illuminating comparison of legislative, judicial, executive and administrative action, and illustrates how the lawyer's concerns tie in closely with the hard facts of government in operation. ${ }^{3}$ Secondly, the presentation of evidence before legislative committees raises issues which are warmly contested and in flux. A drastically edited version of McGrain v. Daugherty 4 is inadequate to convey an impression of the movement of doctrine regarding the compulsion of testimony. ${ }^{5}$ Further, legislative records should be searched for material upon which to discuss standards of scope and procedure in the presentation of evidence in committee hearings. Incidents in the conduct of the Dies Committee, for example, underline the need for the development within legislative tribunals themselves of canons of selfrestraint and precedents of fair and orderly procedure in investigation. As a practical matter, judicial control will be exerted only in extreme cases and then only to enforce constitutional guaranties of minimum decencies;

${ }^{2}$ Concise editorial comment might well supplant the substantial case treatment given questions of executive approval and veto.

${ }^{3}$ See, e.g., Spencer v. Merchant, I25 U.S. 345 (I888); Bi-Metallic Investment Co. v. State Board of Equalization, 239 U.S. 44I (I9I5); Norwegian Nitrogen Products Co. v. United States, 288 U.S. 294 (I933); cf. Townsend v. Yeomans, 30I U.S. 44 I (1937). The editor emphasizes similarities in the functioning of the legislative and judicial processes. See Horack, The Common Law of Legislation, 23 Iowa L. Rev. 4 I (1937). The issue of jurisdictional prerequisites to valid judicial decision is fundamental. It would seem integral to Professor Horack's approach, thus, to consider the question of when notice and hearing may be prerequisite to valid legislative adjudication.

4273 U.S. ${ }_{35}$ (I927).

5 Cf. Kilbourn v. Thompson, 103 U.S. I68 (I880); Harriman v. ICC, 2 II U.S. 407 (Ig08); Jurney v. MacCracken, 294 U.S. r25 (r935); Hearst v. Black, 87 F. (2d) 68 (App. D.C. r936). Here also excellent secondary material is available for use with the cases. 
and there are sound reasons why judicial intervention should go no further. Standards in respect to qualification of witnesses, cross-examination, order of rebuttal, and limitations upon irrelevant and prejudicial matter must be the product of the legislators' own practice. To draw from the body of committee practice sound principles and rules as to these matters is a task peculiarly within the sphere of lawmen. The schools' work in Legislation might here make another of many contributions to the working of government.

Of the legal issues involved in the operation of legislative machinery, a third deserves emphasis. There is a familiar conflict in the decisions regarding the conclusiveness of the enrolled bill as against the evidence of the legislative journals, and of the journals as against still other evidence, in establishing the text of a statute and in determining compliance with constitutional requirements of legislative procedure. This conflict of doctrine is fundamental to the litigation of all questions of the validity of legislative procedure in enactment. Professor Horack underlines this importance by placing the issue at the outset of his treatment of procedural questions. But the deeper significance of the cases, for teaching purposes, lies in the issue of judicial self-limitation, here presented in the highly practical terms of a recurrent problem. This aspect loses force, however, when the conflict of the enrolled bill versus the journal is presented only in the context of legislative mechanics and is not related to the policy questions central to the interpretation of statutes.

\section{THE PRESSURE BACKGROUND OF LEGISLATION}

Apart from legislative machinery, the standard curriculum ignores the extremely important problems which center about the pressure background and around the drafting of legislation. The average law student is an average citizen, in his vague conception that legislation originates either in the initiative of statesmen or among "lobbyists," a term which to him bears exclusively sinister connotations. The shallowness of conventional ideas as to the sources of legislation is fertile ground for unintelligent and reactionary disillusion with representative government. In speaking for a more realistic understanding of the pressures behind law making, the law school can make a significant contribution towards developing intelligent citizenship in its students and in the communities in which they as lawyers will exercise influence.

The relation of this emphasis to professional training is clear. As counsel, the lawyer is increasingly concerned with predicting legislative action. As advocate before legislators, he needs a sound philosophy as to the proper scope of his job. As advocate, judge, or commissioner in a tribunal 
applying legislative regulations, his approach will inevitably be conditioned by some theory of the respect or suspicion which is due the legislative adjustments of community conflicts. Pre-law political science courses may contribute to a general point of view. But here, as is the case regarding the machinery of legislating, the problems go so to the heart of the lawyer's job that the law school needs to pursue the study at the professional level. As it is, a short experience convinces one that few students now obtain even the first factors of a mature political philosophy from their pre-law work. Whatever the proper assessment of responsibility for this failure, the fact justifies the inclusion of a good deal of rather elementary statement in Professor Horack's chapter on "Influencing Legislative Action." Altogether, this chapter offers materials whose breadth and realism sharply challenge conventionally narrow notions of the background of legislative activity. Consideration is not restricted to influences operating directly upon the legislator-his background, the pressure of newspaper and voter and of private and governmental lobbyists. In addition, attention is given to "pre-legislative influences" of organized interest groups and to the effects of the dislocations of social conflict and the inadequacies of private or governmental dealings with them, as provoking statutory change. Restrained pessimism characterizes a review of efforts to regulate election practices and lobbying, with the sound implication that political health cannot be produced by affidavits and lawsuits. ${ }^{6}$

\section{THE CRITICAI CHOICES IN LEGISLATING}

The lawyer today does not have to wait to be elected to public office to become concerned with the drafting of laws. His client's affairs may not reach the dignity of Congressional or state legislation, but there may be the matter of an administrative rule or a county or municipal ordinance to be sponsored, or amendments or substitutions to be drawn as counter moves to proposals by someone else. In any case, he must be more than a mere draftsman, since prior to the business of actually framing legislation there are choices to be made as to content. Professor Horack's casebook excels other Legislation materials which I have had the opportunity to examine in the fullness with which he seeks to outline basic questions of "The Formulation of Legislative Policy."

\footnotetext{
${ }^{6}$ Reference might have been made to the Hatch Act and its amendment, and the materials on regulation of lobbying might include or refer to data from the Canons of Ethics and Opinions of the Committee on Professional Ethics and Grievances of the American Bar Association. See Canons 26 and 36 ; Opinions 8, 26, 98, I48. Discussion of the courts' reluctance to enforce contracts for lobbying services should be compared to the ruling of Fletcher v. Peck, 6 Cranch (U.S.) *87 ( $18 \mathrm{ro}$ ), denying the admissibility of evidence offered to prove corruption in the enactment of a statute.
}

7 See Horack, op. cit. supra note $x$, at c. I. 
There are four such basic questions: (I) whether government should intervene in a given situation at all; (2) which agency should determine policy-legislature, administrative or local government body, the electorate itself, or private groups under government control; (3) what policy should be adopted; and (4) how the policy should be enforced. The law school cannot claim professional competence in the ultimate choices to be made in categories ( $I$ ) and (3). The lawyer's peculiar competence extends no further than to indicate how the choice of legislative agency and of sanctions may or should shape and limit the basic decisions of whether to legislate and what to legislate. Even so restricted, his claims to expert status rest more on default of contestants and on the hazardous intuitions of "common sense" than on any respectable amount of research. Before we can expect a really satisfactory treatment of these problems, we must do a good bit of spade work in the comparative study of official agencies and of sanctions.

It is a reflection upon the lack of solid research in the field generally, then, and not upon the editor's job, to say that the bulk of his source materials here are descriptive rather than critical. The editorial notes bristle with suggestive questions, and carry shrewd comments of a practical nature, derived doubtless from the editor's experience as a legislative counsel. But for the student, questions and notes are relatively barren unless set against a rich record of legislative experience in a field such as this, where expertness must be sought not in terms of formulae but of trained intuition. The bulk of presently available materials-the constitutional and statutory provisions and judicial opinions thereunder - set the framework within which the selection of types of regulations and sanctions must operate. These available materials can illustrate alternative choices. They do not furnish ultimately significant data to guide the choice. This is a point where good treatise material might best be used as the background for discussion of problem cases. But the treatises can be written only on the foundation of specialized studies of which we now have only a scattering. ${ }^{8}$

${ }^{8} \mathrm{Cf}$. Horack, Federal-State Co-operation for Social Security: The Grant-in-Aid, зо Ill. L. Rev. 292 (1935) (excerpts in the casebook); Radin, Popular Legislation in California, 23 Minn. L. Rev. 559 (I939); Handler, False and Misleading Advertising, 39 Yale L.J. 22 (I929); Merwin, Public Relations in Selected Wisconsin Administrative Departments (1937) (unpublished doctoral thesis, University of Wisconsin). Professor Horack presents the fundamental problem, of whether legislative power should be exercised at all in a given situation, in a short but lively section juxtaposing the dogmatism of Herbert Spencer and the factual approach of Dean Pound. As indicated in the text, I do not believe it within the proper sphere of the law curriculum to attempt a more lengthy exploration of ultimate social values. The casebook might well, however, suggest to the student a comparison of the policy issues here with those 
Meanwhile, the present casebook demonstrates that imaginative selection and arrangement of available materials may broaden horizons. Two aspects of Professor Horack's treatment are important contributions to the student's realistic appreciation of the legal system. It directs particular attention to the possibilities of indirect regulation, as by the grant-inaid and by regulation through private associations subject to state supervision. Again, the facts of continuity and precedent in the evolution of legislative policy are stressed as being significant factors in the appraisal of the pressure background and the interpretation of statute law.

\section{PROBLEMS OF DRAFTSMANSHIP}

Probably the most important lessons in the drafting of legislation cannot be taught, but can be gathered only from apprenticeship. Viewing the problem from another angle, many of the legal issues affecting the framing of legislation, like most of those regarding legislative machinery, involve relatively simple and uninspiring material concerning formal constitutional requirements or straightforward devices of arrangement and expression for clarifying the internal structure and meaning of a statute. Questions of construction are of course also involved where the internal structure of the act is relied upon to clarify intention. But, whether the emphasis in questions of punctuation, for example, or the use of permissive and mandatory verbs, be on draftsmanship or interpretation, the elementary character of much of the material recommends the use of a background text plus problem cases in the framing of typical provisions. Professor Horack's arrangement largely follows this device, though the case treatment of some subjects, notably statute titles, seems over-generous.

The casebook, however, does not adequately exploit the possibilities of two very suggestive topics concerning draftsmanship. The first is that of constitutional limitations on special and local legislation. These limitations find expression in a remarkable amount of litigation. They were developed out of the experience of legislative excesses during certain periods of economic exploitation, and there is good reason for inquiring into their continued justification and their aptness today to meet the abuses at which they were aimed. Moreover, the cases, continually raising embar-

of substantive due process. Compare Stone, J., for the Court, in Miller v. Schoene, 276 U.S. 272,279 (I928) ("It would have been none the less a choice if, instead of enacting the present statute, the state, by doing nothing, had permitted serious injury to the apple orchards within its borders to go on unchecked."). This portion of the casebook might also be integrated with the treatment of strict and liberal construction. Compare Cardozo, J., for the Court, in Burnet v. Guggenheim, 288 U.S. 280, 286 (I933) ("The construction that is liberal to one taxpayer may be illiberal to others"). 
rassing issues of form versus substance in the satisfaction of these constitutional limitations, pose questions significant in other fields.

The second problem in draftsmanship, the implications of which justify broader development than this casebook affords, is that of exact expression. A statute may be so indefinite as to violate due process of law. If it is not self-executing, but confers rule-making power upon administrators, the validity of its generality is tested by the more lenient doctrines of delegation of powers. Professor Horack includes basic cases on indefiniteness. But he slights the comparison with delegation doctrine, with its implications for the draftsman in respect to the problems of choice of agencies and types of regulation and sanctions. ${ }^{9}$ Moreover, a wider and richer assortment of material than the constitutional decisions afford is necessary to realize the potentialities of this issue of exact expression. Probably the most fruitful job that a drafting course can hope to accomplish lies in this area, where skill with words must be linked with patience and intelligent appreciation of the facts of the situation to be regulated. The casebook for the course might present the student with exercises in drafting regulatory clauses against the background of stated facts, both of a technical and a rule-of-thumb character, in typical industrial or commercial or governmental problems. ${ }^{x 0}$ Such work should stress the strategic relation between precision or calculated generality in expression and the problem of enforcement.

The due process decisions on indefinite statutory language have obvious importance for the draftsman. They also impress a lesson in advocacy. They teach that if the constitutional requirement is to be applied intelligently, counsel must see that judges appraise statutory terms with adequate understanding of their factual context and of the practical difficulties faced by those who framed the words to meet the facts. The point will be reinforced if the casebook furnishes some experience in drawing provisions to deal with the raw material of the facts involved in regulatory

9 Study of United States v. Cohen Grocery Co., 255 U.S. 8 I (Ig2r), and Connally v. General Construction Co., 269 U.S. 385 ( 1926 ), which the editor reprints, would gain measurably from the inclusion of United States v. Shreveport Grain \& Elevator Co., 287 U.S. 77 (I932), where the Court approved delegation language not dissimilar to that held invalid in the self-executing statutes involved in the other cases. Juxtaposition of Mahler v. Eby, 264 U.S. 32 (r924), with United States v. Ballard, I2 F. Supp. $32 \mathrm{I}$ (Ky. x935), which the editor reprints, and with

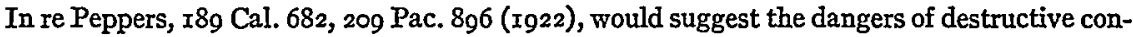
fusion when a self-executing statute is measured by the too lenient test of delegation doctrine, or a delegating statute is found wanting under the too stringent tests of indefiniteness. Compare also United States v. Eaton, I44 U.S. 677 (1892).

ro Cf. Omaechevarria v. Idaho, 246 U.S. 343 (Igr8); Hygrade Provision Co. v. Sherman, 266 U.S. 497 (r925); Bandini Petroleum Co. v. Superior Court, 284 U.S. 8 (r93I); Campbell v. New York, 244 N.Y. 3 I7, x55 N.E. 628 (x927). 
situations. From these aspects the problem of exact expression also is integral to the study of interpretation. The present casebook, however, does little to suggest features of this relationship. It should, for example, call attention to the fact that due process limitations upon indefinite legislation may restrict the application of some familiar canons of construction. . $^{\text {Ix }}$ Thus the casebook might question whether due process in this respect limits the operation of implied repeal or the interpretation of statutes in pari materia. ${ }^{2}$ Or it might suggest that the incidence of doctrines of strict construction may sometimes be better understood when these doctrines are observed as expressions of policies similar to that expressed in the due process doctrine. ${ }^{\mathrm{x}}$

\section{THE STUDY OF INTERPRETATION}

The central problems of interpretation, it might be urged, pervade all courses today and are best handled there. The missionary for Legislation instruction will be content to the extent that his work is further incorporated into the standard subjects, where statutes can be presented in their living context and continuity to a degree denied, by limitations of time and space, to the specialized course. Complete incorporation, however, is an insufficient ideal and one not shortly to be realized. Even when full credit is given, there remains the essential need for helping the student form a working philosophy of the proper relation between law-maker and law-applier. And this job cannot be done adequately without an attempt to convey some practical sense of what constitutes good advocacy, in addition to presenting statutory materials in the matrix of the facts of community life from which statute law comes. The whole task is too critical and too large to be squeezed into the crowded confines of existing courses.

Frailties of foresight and expression, and the impact of variety and change in the situations regulated, mean that judges and administrators must legislate interstitially in statute as well as in common law. Those who thus legislate in the application of policy must do so with a sympa-

${ }^{x}$ See Yu Cong Eng v. Trinidad, 27 I U.S. 500, 518 (I926) (a statute will not be construed in a way to avoid a grave constitutional question where the alternative construction itself is unfairly indefinite); Smith v. Cahoon, 283 U.S. 553,564 (I93I) (construction of statute invalid in some applications as intended to operate wherever application would be constitutional will not be made where scope of act would thereby be rendered unfairly indefinite). See Horack, op. cit. supra note I, at $692 \mathrm{n}$. I, $780 \mathrm{n}$. I.

'2 See State v. Wentler, 76 Wis. 89, 44 N.W. 84 I (I89o).

${ }^{13}$ See Hall, Strict or Liberal Construction of Penal Statutes, 48 Harv. L. Rev. 748 (I935). This suggestion should be compared with the cases included by the editor relative to the question whether more stringent requirements of definiteness apply to penal than to civil statutes. Compare Cardozo, J., in Campbell v. New York, 244 N.Y. 317,329 , 155 N.E. 628, 63 (I927), with A. B. Small Co. v. American Sugar Refining Co., 267 U.S. 233, 239 (I925). 
thetic comprehension of policy, if we are to have the substance of representative government, and if government is not to be stalled by interagency conflict. This need makes the concept of the "intention of the legislature" the central one in the study of interpretation. Of what propositions is the concept formed? What is its significance as a canon of selfrestraint in the administration of legislative regulations? How should we assess its reality or lack of reality in light of the facts as to how legislative and adjudicative functions are conducted?

The best of judicial opinions are relatively barren stuff with which to introduce this field, and there are few enough which are compounded of anything but empty generalities. Insight and time will be gained by generous use of secondary readings, though this is another point at which construction of the ideal Legislation casebook awaits more spadework in specialized background studies. Professor Horack begins his selection with a bow towards semantics, and also prints extracts from the classic exchange of Radin and Landis and from his own suggestive commentary on this debate. ${ }^{\mathrm{I}}$ This is all first-rate, except that the editing is too drastic. In view of the fundamental and subtle character of the issues, the student ought to have a chance to sharpen his understanding on the full text of explorations and arguments by able thinkers. Moreover, in eliminating portions of the Radin-Landis exchange dealing most particularly with the rationale of the judicial obligation to follow legislative intention, once ascertained, the editor needlessly obscures the deepest implications of the problem.

For discussion based upon the secondary readings, decisions pursuing the "equity of the statute," where the law because of its generality or its particularity covers too much or too little, contrast well with decisions insisting on the compelling force of the "literal" meaning. The editor's selection here is stimulating and acquaints the student with some of those few decisions entitled to be called "leading cases" in interpretation. ${ }^{\mathrm{x}}$ There is ample room for experiment in selection of case material focusing on the question of the "intention of the legislature." For example, the rationale of that concept and the definition of the proper scope for judicial action in filling statutory gaps, are nowhere better presented than in questions of the applicability of statutes to states of fact not existent or reasonably foreseeable at the time of enactment. As problems for sound ad-

${ }_{14}$ Radin, Statutory Interpretation, 43 Harv. L. Rev. 863 (1930); Landis, A Note on Statutory Interpretation, 43 Harv. L. Rev. 886 (I930); Horack, In the Name of Legislative Intention, 38 W. Va. L. Q. Ir9 (I932).

Is Notably, Church of The Holy Trinity v. United States, I43 U.S. 457 (x892), and Caminetti v. United States, 242 U.S. 470 (IgI7). In both instances the editing, again, seems too severe. 
vocacy and decision, such cases are lively teaching material and would repay a more detailed treatment than the limits of this casebook allow. ${ }^{16}$

Inextricably linked with the fundamental concept of legislative intent, of course, is the use of data extrinsic to the statute for purposes of interpreting it. Professor Horack's arrangement is admirably calculated to arouse the student's imagination to the possibilities here, comparing the use of legislative documents with evidence of administrative interpretation, judicial notice of the history of the times, the accretion of interpretative precedent, and the effect of practical construction by the parties affected. Shortcomings are, again, not of inclusion but of omission. Thus, the casebook's material on the use of legislative records tends to be merely descriptive of rules, and only meagerly reflects the growth toward liberal doctrine in this area. In addition, the cases are too much cut to the bare bones of doctrine to furnish the student adequate data for appraising the merits of evidence drawn from legislative records. At another point, the casebook reprints colorful examples of committee hearings and reports and floor debate, but the value of these extracts would be greater if they could be drawn from the history of statutes later involved in cases treating the use of such extrinsic evidence. In a course where the bulk of the material necessary to convey the sense of living law will always cause practical difficulties, there is a highly utilitarian reason for selecting materials capable of double duty. Contrasting English material on the use of extrinsic sources for interpretation is not presented. Reprints from a pair of good, adversary briefs would, in any event, probably furnish teaching material superior to cases at this point.

\section{INTERPRETATION: THE ROLE OF THE ADVOCATE}

Whether regarded as training for sound advocacy or decision, the theme on which the study of interpretation should play many variations is that of tireless insistence on uncovering all the very particular facts of history and policy in which a given interpretative problem is imbedded. After the discussion of the central concept of legislative intention, we can safely forego generalization as a major emphasis and stress particularity. It is in the latter aspect that the typical approach in judicial opinion or law-

\footnotetext{
${ }^{16}$ Cf., e.g., Doherty v. Inhabitants of Ayer, I97 Mass. 24r, 83 N.E. 677 (I908) (automobile not a "carriage" within an 1882 act requiring that town roads be maintained in condition safe for carriages); Commonwealth v. Quaker City Cab Co., 287 Pa. I6I, I34 Atl. 404 (I926), rev'd on other grounds 277 U.S. 389 (r928) (application of 1889 tax act to taxicab companies); Fox Film Corporation's Application, 295 Pa. 46I, x45 Atl. $5 I_{4}$ (I929) (application of I9I5 movie censorship act to sound pictures). Comparison should be made with the question of applicability of constitutional provisions to changed conditions. Cf. Pensacola Tel. Co. v. Western Union Tel. Co., 96 U.S. I (I877) (telegraph operations within commerce clause). See Holmes, J., in Missouri v. Holland, $25^{2}$ U.S. 4r6, 433 (rg20).
} 
yer's brief is most fumbling. "But every question of construction is unique, and an argument that would prevail in one case may be inadequate in another."I7 This emphasis is simply stated, but not easily taught, as anyone who has tried it, knows.

Two types of problems are particularly adapted to this end; a major lack in the present casebook is that it does not supply adequate material for their exploration. Both source and secondary materials should be presented in variety sufficient to demonstrate the diverse ideas of policy and assumptions of fact which the decisions and treatises lump together under single "rules" of strict and liberal construction. Such worn admonitions as those counseling the strict construction of penal statutes or of statutes in derogation of the common law should be broken down into the different choices and emotions which they express, and a more particular rationale demanded of each particular line of decision. ${ }^{x 8}$ The second question deserving emphasis, though in logical symmetry it may not classify as the study of interpretation, is that of the use of statutes by analogy to furnish principles or standards of decision at common law. ${ }^{\text {.9 }}$ Frequent resort to penal statutes in defining standards of prudent conduct in civil actions for negligence and in the definition of contracts illegal as contrary to public policy recommends these examples for development. Doctrine is still confused and technique uncertain in this use of legislative material. Proper appreciation of the utility of statutory materials for these ends depends peculiarly upon familiarity with the legislative process and sound habits of craftsmanship in searching out the factual background of legislation. Adequately investigated, the problems demand more time than the limits of torts and contracts courses allow. ${ }^{20}$ And there is a deeper justification for time spent in discussing the analogical use of statutes. The student,

17 Holmes, J., in United States v. Jin Fuey Moy, 24I U.S. 394, 402 (I9I6).

${ }^{8}$ Thus Pound, Common Law and Legislation, 21 Harv. L. Rev. 383 (rgo8), and Hall, Strict or Liberal Construction of Penal Statutes, 48 Harv. L. Rev. 748 (I935), provide fertile ground for discussion, in combination with varied case material. Cf. Jennings, Courts and Administrative Law-The Experience of English Housing Legislation, 49 Harv. L. Rev. 426 (1936); Pound, The Formative Era of American Law c. II (I938); Stone, The Common Law in the United States, 50 Harv. I. Rev. 4 (I936); Harvard Tercentenary Publications: The Future of the Common Law I2o (r937). See Horack, op. cit. supra note $x$, at 55 I n. I, $55^{2}$ n. 2.

I9 Interpretative use of statutes in pari materia and resort to fundamental legislation or lines of legislative development to supply guiding principles of construction in broad areas of regulation are topics more strictly within the category of interpretation which should be integrated in discussion with the question of analogical use of statutes. Cf. Karnuth v. United States, 279 U.S. 23I, 243 (I929); Healy v. Ratta, 292 U.S. 263, 269, 270 (I934); Wisconsin Granite Co. v. Industrial Com'n, 208 Wis. 270, 279, 242 N.W. I9r, I94 (I932).

${ }^{20}$ Compare Lowndes, Civil Liability Created by Criminal Legislation, 16 Minn. L. Rev. 36I (1932), with Morris, The Relation of Criminal Statutes to Tort Liability, 46 Harv. L. Rev. 453 (1933). See Gellhorn, Contracts and Public Policy, 35 Col. L. Rev. 679 (r935). 
as the judge or lawyer, tends to regard the statute book simply as a rule book, of no concern to him unless he finds written there a specific answer to his problem. Nothing is better calculated to dissipate this provincialism and to reveal the statute book as a flexible and enriching source for creative legal thinking than the study of statutes not as rules but as responsible findings of fact and expressions of felt needs of society.

\section{THE ARRANGEMENT OF LEGISLATION COURSES}

Listing the types of legislative problems which deserve specialized treatment does not answer the question of how to organize these problems into a course. The arrangement and content of Professor Horack's casebook imply that at best Legislation will be allotted one course in the curriculum, probably a single semester of two or three hours. It is clear that the editor would regard this allocation as based upon practical and not ideal considerations. His collection represents about as sound a piece of construction as is likely to be done for a course of this scope. Because the book is a good job, its inadequacies are the more persuasive of the essential inadequacy of an attempt to handle Legislation within the confines of a single volume. Most of the criticisms that may be made of the casebook relate not to its conception of the scope of the field or its ordering of topics, but to the sketchiness of its materials. Yet, even as it stands, it is too full to fit comfortably into a single course.

\section{IEGISLATION IN AN ORIENTATION COURSE}

A practical solution may lie in emphasizing the legislative process as part of a first-year orientation course, upon which can be built advanced work in the legislative function and the interpretation of statutes. At Wisconsin we have begun such an experiment with the establishment of an orientation course which we call Law in Society. ${ }^{2 x}$ Meeting four times a week for one semester, the course begins with twelve hours of lectures and discussions describing and comparing the structure and functions of major legal agencies and raising basic questions of the meaning of law and the nature of interests. Extensive editorial comment and excerpts from secondary readings make up most of the reading matter in this opening portion, though illustrative case and statutory materials are also employed. The whole is given continuity by its arrangement about a framework provided by the record and opinions reprinted from a case involving judicial review of an administrative award under the Wisconsin workmen's compensation act. The various materials are thus invoked successively to explain the significance of the stages in this actual litigation.

${ }^{2 x}$ Compare the use of legislation in the first year program at the Law School of Columbia University. See Parkinson, Cases and Materials on Legislation (rev. ed. I936). 
Following this introduction, the remaining three-quarters of the course are built upon material reflecting the evolution of legal doctrine pertaining to industrial accident. After a discussion of the earliest English and American cases creating the fellow servant rule, attention is concentrated entirely on Wisconsin sources reflecting the turning points in the Wisconsin development from common law, through employers'-liability legislation, to the compensation act. Materials are not confined to statutes and cases, but include excerpts from briefs of counsel and from legislative, executive and administrative records, portions of party platforms, and of the minutes of proceedings of leading pressure groups such as the state federation of labor, together with first-hand accounts of the background of the compensation act by persons prominent in its enactment.

Only half the readings, however, involves the problem of industrial accident. The remainder consists of treatise and law review selections discussing general juristic problems implicit in the industrial accident materials. Thus, after the first cases on the fellow servant rule, readings are introduced regarding the nature of conflicts of interests, the litigious process as a method of law-making in the adjustment of conflicts, and limitations of ignorance and economic bias in the judicial process. Again, Wisconsin cases giving restrictive interpretation to early employers'-liability legislation are presented in conjunction with readings discussing elementary concepts of judicial responsibility toward statute law, the continuity of legislative policy, and the historical and emotional background of the "rule" of strict construction of statutes in derogation of the common law. At every point possible, the effort is made to integrate the discussion of the secondary readings with the implications of the primary sources studied.

Several basic points in the theory of the course are relevant to the practical problems of teaching Legislation. First, concentration upon the evolution of legal efforts to meet a particular community problem places the legislative process in living comparison with judicial and administrative activity. There is scope in such a course especially for detailed comparison of litigious and legislative law-making. ${ }^{22}$ Second, focusing the course upon the unfolding of a single problem gives the time and space necessary to a convincing re-creation of the life and movement behind fundamental legislation. Professor Horack makes good use of this device in a more limited fashion; for example, to introduce his consideration of interpretation, he uses successive statutory and case material regarding the application of the

${ }_{22}$ The Wisconsin course, from limitations of time, considers different legal agencies with reference chiefly to policy-making and does not undertake any extensive exploration of problems of sanctions. 
anti-trust laws to trade union activity. ${ }^{23}$ In whatever degree adopted, such continuity of materials on some connected topic seems essential to a convincing presentation of important aspects of legislation. ${ }^{24}$

The third emphasis in the construction of the course is the integration of primary sources with secondary readings, in about equal bulk. Text material in current casebooks is apt to be drained of its natural vigor and color because excerpts are restricted to the minimum necessary to convey the writer's thesis. Such drastic editing is justifiable where text is substituted for cases simply because it is a more efficient means of conveying information. But in statutory interpretation, for example, the difficulty with the cases is that their doctrine is muddled and vague and filled with question-begging generalities. What the student needs here is opportunity to gain a sense of direction and perspective and to toughen his mind by pitting the rationalizations of legislative and judicial language against the wit and penetration of good essayists. For this he must be given not snippets but the full body of chapters and articles. This generosity will probably mean that within the practicable limits of the casebook one can "cover" less ground, but the test of material is in maturity and not area.

Finally, material in the Wisconsin orientation course has been selected and arranged wherever possible to emphasize the responsibilities and opportunities of sound counsel and advocacy. It is important to train future legislators, judges, and commissioners. Most law students, however, will not hold public office. Yet, what government can accomplish is inseparably related to the attitudes and training which the bar brings to problems

${ }^{23}$ Thus, he also employs connected series of materials on the regulation of building construction, gambling, and milk to bring out points concerning the formulation of legislative policy. Excerpts from committee and floor consideration of the Securities Exchange Act lend reality to the chapter on legislative procedure; I have suggested above that it would be desirable if material selected at this point could relate to questions later actually in litigation. The chapter on the pressure background of legislation is built around materials illustrating different phases of the struggle for regulation of hours of labor over the course of a century. The treatment here seems less successful; perhaps concentration on a more limited period or issue would be desirable.

24 Primary sources used in the Wisconsin orientation course are almost entirely drawn from Wisconsin records; out-of-state materials are brought into the picture only at decisive points where the Wisconsin evolution touched outside influences. The basis of selection is not parochial pride. So long as the problem dealt with is important and has left a rich and colorful record, such concentration upon events in one line of development within one jurisdiction seems most likely to create for the student a convincing sense of the continuity and depth of policy. The greater variety and detail of documents generally available with reference to Congressional legislation might suggest that the framework of such a course would better be found in some important line of federal policy. The bulk of the average lawman's concern, however, is with state law, and the very generosity of federal sources makes their study somewhat atypical; closer to the student's needs may be training in searching out and using the scantier sources in the background of state policy. 
of government. Proper understanding of regulatory issues by official agencies is measurably conditioned by the breadth and imagination in lawyers' presentations of the interests involved. Moreover, only a small part of the necessary ordering of a democratic society can be done by the official agencies. Legislation, decision, and administration go forward in every law office. The lawyer's day-to-day work of consultation, draftsmanship, compromise, demand, and enforcement, and the wisdom which go into these, are critically important to making the wheels go around in an organized community. It is no empty phrase to say that the lawyer is an officer of the court; indeed, more accurately, he is an officer of the state. But law courses still leave largely unspoken the implications of their materials for training in the wisdom and craftsmanship of the counsellor and advocate. Previous lack of exploration particularly demands more explicit stress on these aspects of the lawman's relation to the shaping and application of legislative policy.

\section{ADVANCED LEGISLATION COURSES}

The elementary study of the legislative process in such an orientation course should lay the foundation and save the time of advanced courses. Legislative organization and procedure, the pressure background of legislation, and draftsmanship with its underlying choices as to type of regulation and sanctions, are important in their own right. They are also obviously desirable background for the study of interpretation. If possible, they should be formed into an advanced three-hour semester course given as a prerequisite to three hours in the second term for study of interpretation. Practical limitations may not permit this generosity. In that case, even allowing for the benefits of a first-year foundation course, it seems wiser not to attempt to touch all of the detailed problems in a single semester course. A defensible choice, which I have thought justified by experience, is a three-hour semester course centering on the concept of the intention of the legislature, around which may be built the problems of the use of extrinsic evidence of legislative intent, of doctrines of strict and liberal construction, and of the use of statutes by analogy in tort and contract litigation. The first third of this course, moreover, I have devoted to materials concerning the scope and technique of trials involving issues of the constitutionality of statutes: the concept of political questions, the transitional doctrine of the finality of the enrolled bill to establish statutory text and procedural validity, and a detailed study of the "presumption of constitutionality" as determinative of the burden of proof and of the procedure in the trial of issues of constitutional fact. ${ }^{25}$ There is more

\footnotetext{
${ }^{25} \mathrm{Cf}$. Parkinson, op. cit. supra note 2I, at c. $\mathrm{III}$.
} 
room in Legislation than in the constitutional law course for adequate consideration of the trial of constitutional issues. There, also, it provides a first rate introduction to the study of interpretation. For the canons of judicial self-limitation and the insistence upon full exploration of facts conditioning the validity of statutes, which are expressed in the "presumption of constitutionality," set out in broader and simpler strokes the ideas which are fundamental in appraising the process of statutory interpretation.

Today administrative legislation presents a new center of interest, raising its own problems of draftsmanship, representation and activity of pressure groups, and interpretation of rules. To assume that legislative problems are alike, without regard to the peculiar structure and tasks of the law-making body, begs fundamental questions. Though practical limitations will concentrate study on the functioning of the principal legislature, appraisal will be keener by constant comparison with problems of statute making by administrative and local government bodies. Professor Horack indicates that he would integrate the content of the courses in legislation and administrative law, to develop this sort of comparison. That seems a highly practical solution, as it also suggests how emphasis on legislative problems may lend new vigor to the established curriculum. But comparative study of legislative problems in the context of different agencies has too much immediate relevance to the study of Legislation to be left mainly to other courses. The present casebook stresses material dealing with the choice of law-making body, as a problem in the formulation of policy. It should develop this approach more fully, however, and especially should an advanced Legislation course present issues of interpretation as they may vary according to the problems and capacities of the various types of statute-making agencies.

From a detailed consideration of the desirable content of Legislation instruction there emerges something much more complex than merely the matter of adding a course to the law curriculum. What is needed is the integration of a new emphasis into the whole law training. The justification for that effort runs so deep into the law school's responsibilities for education in the philosophy and craftsmanship of the profession, that it cannot be denied in the reformation of the curriculum to meet the needs of our society. These responsibilities are not met by offering a Legislation seminar to a handful of students. Granted, there is pressing need for plenty of seminar research. Still, the goal must be the creation of courses of general instruction which shall become a root part of every student's legal education. 